Dominik J. Kościuk

Uniwersytet $w$ Biatymstoku

\title{
ZRÓWNOWAŻONY ROZWÓJ A PAPIEROWA BIUROKRACJA ADMINISTRACYJNA
}

Aparat pomocniczy organów administracji publicznej w Polsce to tysiące urzędów, jednostek organizacyjnych, urzędników oraz jeszcze więcej działań i czynności wymagających użycia papieru. Co ważne - z punktu widzenia ochrony środowiska i zasady zrównoważonego rozwoju - do produkcji papieru wykorzystywanych jest około połowy światowych zasobów drewna, będącego w obrocie rynkowym. Według badań przeprowadzonych przez National Geographic, na produkcję papieru zużywana jest duża część z 9 milionów hektarów lasów wycinanych każdego roku. ${ }^{1}$ W literaturze podnosi się, że jedynie część drewna pochodzi z wycinki racjonalnie zarządzanych zasobów leśnych, jednakże większość ,...pozyskiwana jest w wyniku nieodpowiedzialnego zarządzania lasami, w tym z nielegalnych wycinek i niszczenia zasobów leśnych o szczególnej wartości przyrodniczej oraz z monokulturowych plantacji przemysłowych (np. upraw drzew eukaliptusa, nazywanych powszechnie zielonymi pustyniami)."2 Wspomniani autorzy twierdzą, że corocznie odnotowuje się przyrost w produkcji i konsumpcji papieru, a jednocześnie przewidują, że światowa sprzedaż tego surowca, w okresie od roku 2010 do roku 2050 wzrośnie o 100 mln ton (z 400 do $500 \mathrm{mln}$ ton). Również w Polsce odnotowuje się poważny przyrost konsumpcji papieru. A. Żwawa - powołując się na dane Stowarzyszenia Papierników Polskich - pisze, że w roku 2002 przeciętne zużycie papieru na mieszkańca Polski oscylowało wokół $65 \mathrm{~kg}$, natomiast w roku 2015 wskaźnik zużycia wzrośnie do $115 \mathrm{~kg}^{3}$ Wydaje się jednocześnie, że na ów wzrost niebanalnie wpływa działalność administracji publicznej, która wraz ze zwiększaniem liczby realizowanych zadań publicznych, zwiększa zapotrzebowania na papier, wykorzystywany w działalności biurokratycznej. Tym samym można założyć, iż administracja publiczna

\footnotetext{
$1 \quad$ Na badania National Geographic powołuje się J.Berdo w monografii: Zrównoważony rozwój - w stronę życia w harmonii z przyrodą, Sopot 2006, s. 2.

2 Tak twierdzą: A. Żwawa, M. Noszczyk, M. Huma, Przemysł drzewno-papierniczy, http://www.ekonsument.pl/ a66525_przemysl_drzewno_papierniczy.html [online 09.09.2013 r.].

3 A. Żwawa, Piły i piłki - nie kibicuj niszczeniu lasów!, http://zielonewiadomosci.pl/tematy/ekologia/pilki-i-pily-niekibicuj-niszczeniu-lasow/ [online 09.09.2013 r.].
} 
w Polsce nie realizuje - w omawianym aspekcie - założeń zasady zrównoważonego rozwoju. Aby jednak choćby częściowo potwierdzić owe założenie, należałoby wyjaśnić, czym jest zasada zrównoważonego rozwoju i odpowiedzieć na pytanie, czy istnieją spójne i jednolite podstawy prawne ograniczania zużycia papieru w działaniach „sfery biurokratycznej”. Oczywiście, istnienie spójnego prawa nie przesądza jeszcze o jego wykonywaniu, jednakże badanie jedynie „samego" prawa podyktowane jest faktem, iż nie ma - moim zdaniem - problemu w identyfikacji rozwiązań praktycznych dotyczących realizowania celów zasady ZR, takich jak: działania mające na celu ochronę bioróżnorodności, wdrażanie rolnictwa ekologicznego, stosowanie odnawialnych źródeł energii, czy też zrównoważone gospodarowanie zasobami wodnymi i leśnymi.

Pojęcie zasady zrównoważonego rozwoju (dalej zwanej zasadą ZR) zostało w literaturze opisane wielokrotnie i nie stanowi problematyki kontrowersyjnej. Między innymi, A.Krzywoń stwierdza, że jest to dyrektywa zawierająca wytyczne działalności prawotwórczej, która wymaga od prawodawcy ,...ciągłej optymalizacji całego systemu prawa, tak aby w odpowiednim do danych okoliczności stopniu i z poszanowaniem zasady proporcjonalności uwzględniał on jednocześnie potrzebę ciągłego rozwoju (w tym prawa i wolności jednostek) oraz wartości ogólnospołeczne, w szczególności ochronę środowiska."4

W wysokim stopniu abstrakcji wypowiada się M. Stoczkiewicz, który wyprowadzając definicję z przepisu art. 5 Konstytucji RP pisze, że zasada zrównoważonego rozwoju to norma nakazująca wszystkim organom państwa dążenie do osiągnięcia stanu zrównoważonego rozwoju, przy czym owe dążenie rozumie bardzo ogólnie, jako obowiązujące zawsze i we wszystkich działaniach. ${ }^{5}$

Podobnie pisze Z. Bukowski, odnosząc analizowaną zasadę do wszystkich wymienionych w art. 5 Konstytucji podstawowych funkcji państwa, co ma potwierdzać jej funkcje ustrojowe, wiąże ją ściśle z ochroną środowiska. ${ }^{6}$ Ten sam autor, uszczegóławiając tezę o związku zasady zrównoważonego rozwoju z podstawowymi funkcjami państwa, potwierdza, że chodzi o wszystkie organy państwa, a więc zarówno ustawodawcze, wykonawcze i sądownicze, w całej ich działalności. Ów autor uważa, że konsekwencją tworzenia prawa z pominięciem zasady ZR jest możliwość bezpośredniego zaskarżania aktów normatywnych do Trybunału Konstytucyjnego. ${ }^{7}$

M. Roliński również bardzo ściśle wiąże zasadę ZR z definicją ochrony środowiska. Pisze on, że oparcie definicji legalnej ochrony środowiska na zasadzie zrównoważonego rozwoju spowodowało zmianę charakteru podejmowanych przez państwo działań ochronnych. Aktualnie - według tegoż autora - należy pojmować

4 A. Krzywoń, Konstytucja RP a środowisko, „Państwo i Prawo” 2012, nr 8, s. 3.

5 M. Stoczkiewicz, Zasada zrównoważonego rozwoju, jako zasada prawna, „Prawo i Środowisko” 2001, nr 1, s. 122.

6 Z. Bukowski, Konstytucyjne podstawy obowiązków państwa w zakresie ochrony środowiska, „Prawo i Środowisko" 2002, nr 4, s. 63. Ibidem, s. 63 
zadania ochronne z punktu widzenia podmiotowego, tj. należy tak chronić poszczególne elementy środowiska, aby mieć na uwadze przede wszystkim ochronę życia i zdrowia ludzi. ${ }^{8}$

Z kolei J. Maciejewska opisywaną zasadę wiąże z bezpieczeństwem ekologicznym. Stwierdza ona, że owe bezpieczeństwo ,..to stan środowiska nie zagrażający zdrowiu i życiu człowieka, w którym organy państwowe zapobiegają klęskom żywiołowym i minimalizują skutki owych klęsk oraz kierują rozwojem społecznogospodarczym w sposób zrównoważony i zapewniający godne warunki do życia współczesnym i przyszłym obywatelom." Wydaje się to oznaczać, iż organy administracji publicznej powinny podejmować swoje działania (w aspekcie społecznym, politycznym, gospodarczym itp.) mając na uwadze zapewnienie odpowiednich warunków ekologicznych i środowiskowych nie tylko w chwili podejmowania działań, ale również w perspektywie wieloletniej.

Bardzo ogólne, ale tym samym uproszczone pojęcie zasady ZR zaprezentował M. Gerwin, pisząc, że jest to dążenie do poprawy jakości życia, przy zachowaniu równości społecznej, bioróżnorodności i bogactwa zasobów naturalnych. Autor, określając cel istnienia tej zasady stwierdza, że: „Rzecz w tym, aby dążąc do dobrego życia nie zniszczyć przyrody, od której uzależnione jest życie na Ziemi, nie wyczerpać wszystkich zasobów naturalnych (...), ani też dążąc do poprawy własnego życia, nie skazywać na biedę innych."10

Widoczne jest zatem (w doktrynie) bardzo spójne pojmowanie zasady ZR, w szczególności poprzez związanie jej z Konstytucją RP i postulatami ochrony środowiska we wszelakiej działalności publicznej. Skoro zatem działania - w których winna być realizowana ochrona środowiska - rozumiane są tak szeroko, oznacza to, że obejmują również działalność biurokratyczną administracji publicznej. Jak zatem - do przestrzegania zasady ZR - ma się powszechnie znana praktyka zużywania znacznej ilości papieru przez urzędników państwowych i samorządowych? Czy istnieją skuteczne i jednolite regulacje prawne umożliwiające (w tym aspekcie) unikanie takiego nieekologicznego zużycia? Aby odpowiedzieć na to pytanie, należy odpowiedzieć na pytanie, czy istnieją spójne i jednolite przepisy (akty normatywne) umożliwiające ograniczenie ,,papierologii”, a co za tym idzie konieczna jest analiza obowiązujących przepisów prawa, zarówno od strony ustrojowej (tj. zobowiązującej lub umożliwiającej realizację zadań publicznych w drodze elektronicznej), jak i proceduralnej (tj. określającej prowadzenie procedury administracyjnej on-line.)

Zasadnicze znaczenie - z punktu widzenia biurokracji - ma ustawa o informatyzacji działalności podmiotów realizujących zadania publiczne. ${ }^{11} \mathrm{Ma}$

8 M. Roliński, Ewolucja pojęcia prawnego „środowiska” i „ochrona środowiska”, „Studia luridica Lublinensia” 2005, $\mathrm{nr}$ 6, s. 159.

9 J. Maciejewska, Bezpieczeństwo ekologiczne, jako konstytucyjny obowiązek państwa, PPOŚ 2009, nr 2, s. 59.

10 M. Gerwin, Plan zrównoważonego dostępu dla Polski. Lokalne inicjatywy rozwojowe, Sopot 2008, s. 3.

11 Ustawa z dn. 17 lutego 2005, o informatyzacji działalności podmiotów realizujących zadania publiczne, Dz.U. Nr 64, poz. 565, ze zm. (zwana dalej ustawą o informatyzacji, albo uinf). 
ona na celu doprowadzenie do wiążącego wpływu Państwa na procesy informatyzacyjne podmiotów publicznych, głównie poprzez ustalanie jednolitych, minimalnych i gwarantujących otwartość standardów informatycznych, ustalanie specyfikacji rozwiązań stosowanych w oprogramowaniu umożliwiającym łączenie i wymianę informacji, a przede wszystkim ustalenie zasad wymiany informacji w drodze elektronicznej, w tym dokumentów elektronicznych, pomiędzy podmiotami publicznymi a niepublicznymi. ${ }^{12}$

Jednocześnie kluczowe znaczenie mają przepisy art. 13 do art. 15 uinf. Określono tamże obowiązki (względem podmiotów wdrażających narzędzia teleinformatyczne w administracji) dążenia do stanu pełnej kompatybilności wszystkich systemów i rejestrów, aby możliwa była wymiana między nimi informacji w drodze elektronicznej. Jednocześnie uinf $\mathrm{w}$ art. 3 ust. 9 wskazuje na cechy i wymagania organizacyjne oraz techniczne tychże systemów i rejestrów. Ma to na celu doprowadzenie do umożliwienia bezpośredniej komunikacji nie tylko między podmiotami realizującymi zadania publiczne, ale i petentami zainteresowanymi rozstrzygnięciami administracji, bez względu na stosowane urządzenie służące do komunikacji elektronicznej oraz system operacyjny zainstalowany na tym urządzeniu. „Minimalne wymagania" powinny - między innymi - umożliwić stworzenie i wdrożenie aplikacji mobilnych, oprogramowania działającego na wszystkich najpopularniejszych systemach operacyjnych (np. Windows, OS X, Linux, Android itp.). Niedopuszczalne jest dookreślanie przepisami prawa konkretnych, będących w użyciu aplikacji komputerowych. Przykładowo nie powinno się zawierać w przepisach wykonawczych sformułowań sugerujących możliwość użycia (jako standardu publicznego) edytora tekstu MS Word. Taki edytor przeznaczony jest z zasady do systemu operacyjnego Windows, podczas gdy np. system operacyjny OS X jest „powiązany” $\mathrm{z}$ edytorem Pages. Dodatkowo należy zwrócić uwagę na ustawowe zobowiązanie publikowania w BIP struktur dokumentów elektronicznych, formatów danych czy protokołów szyfrujących i komunikacyjnych. ${ }^{13}$ Dzięki temu - z założenia - umożliwia się przedsiębiorcom informatycznym i programistom tworzenie komercyjnego $\mathrm{i}$ bezpłatnego oprogramowania kompatybilnego z całością systemu wymiany informacji w administracji publicznej.

Co więcej, minimalne wymagania systemów teleinformatycznych w użyciu podmiotów realizujących zadania publiczne zostały uszczegółowione w Rozporządzeniu Rady Ministrów w sprawie minimalnych wymagań dla systemów teleinformatycznych. ${ }^{14}$ Wymienia się tam protokoły komunikacyjne i szyfrujące umożliwiające międzysystemową wymianę danych, rodzaje rozszerzeń plików zawierających in- 
formację w formie tekstu lub grafiki, czy też formaty danych do tworzenia i modyfikacji stron www.

Natomiast z niezwykle (aby nie napisać „zbyt”) szczegółową regulacją mamy do czynienia w Rozporządzeniu w sprawie minimalnych wymagań dla rejestrów publicznych i wymiany informacji w formie elektronicznej. ${ }^{15}$ Prawodawca postanowił na tyle konkretnie zaingerować w tworzone rejestry informatyczne, że wskazał nawet na konieczną liczbę znaków w polach alfanumerycznych tworzonych formularzy elektronicznych. ${ }^{16}$

Standaryzacja systemów informatycznych i rejestrów publicznych została potwierdzona $\mathrm{w}$ art. 16 uinf. Prawodawca nakazał podmiotom realizującym zadania publiczne stworzenie warunków technicznych do sporządzania, wymiany i doręczania dokumentacji $\mathrm{w}$ formie elektronicznej $\mathrm{w}$ ramach realizowanych spraw administracyjnych. Szczegółowe regulacje w tym zakresie zostały zawarte w Rozporządzeniu Prezesa Rady Ministrów w sprawie sporządzania pism w formie dokumentów elektronicznych, doręczania dokumentów elektronicznych oraz udostępniania formularzy, wzorów i kopii dokumentów elektronicznych. ${ }^{17}$ Ów akt normatywny szczegółowo reguluje warunki organizacyjne i techniczne doręczania dokumentów elektronicznych (w tym tworzenia skrzynki podawczo-odbiorczej oraz wykorzystania platformy ePUAP), sposób ich doręczania oraz poświadczania odbioru. Regulacje odnoszą się do tak konkretnych zagadnien, jak moduły kryptograficzne stosowane w systemach teleinformatycznych, problematyka elektronicznych nośników danych, czy też zabezpieczenie przed nieuprawnioną ingerencją w treść dokumentacji. ${ }^{18}$

Równie istotne znaczenie mają przepisy umożliwiające wdrożenie i wykorzystanie elektronicznej platformy usług administracji publicznej (dalej ePUAP lub Platforma). Platforma jest narzędziem służącym do administrowania danymi, komunikacji elektronicznej oraz udostępniania usług administracji. Umożliwia ona tworzenie i obsługę dokumentów elektronicznych, ich przesyłanie, międzysystemową wymianę danych, identyfikację użytkowników i „rozliczalność” ich działań, tworzenie konkretnych usług administracyjnych, weryfikację podpisu elektronicznego, potwierdzanie profilu zaufanego oraz weryfikację płatności dokonanych za pomocą narzędzi elektronicznych. Organem właściwym do zapewnienia jej funkcjonowania jest Minister właściwy do spraw informatyzacji. ${ }^{19}$ Ów organ - oprócz ustalania stan-

\footnotetext{
15 Rozporządzenie Rady Ministrów z dn. 11 października 2005 r. w sprawie minimalnych wymagań dla rejestrów publicznych i wymiany informacji w formie elektronicznej, Dz.U. Nr 214, poz. 1781.

16 Zob. załącznik do Rozporządzenia Rady Ministrów w sprawie minimalnych wymagań dla rejestrów publicznych i wymiany informacji w formie elektronicznej.

17 Rozporządzenie Prezesa Rady Ministrów z dn. 14 września 2011 r. w sprawie sporządzania pism w formie dokumentów elektronicznych, doręczania dokumentów elektronicznych oraz udostępniania formularzy, wzorów i kopii dokumentów elektronicznych, Dz.U. Nr 206, poz. 1216 (dalej jako Rozporządzenie w sprawie sporządzania pism).

18 Zob. §14 Rozporządzenia w sprawie sporządzania pism.

19 Zob. art. 19a uinf.
} 
dardów technicznych działania ePUAP - jest administratorem tzw. „,entralnego repozytorium" pism administracyjnych, przy czym repozytorium jest niejako zbiorem wzorów pism używanych w prowadzonych przez administrację publiczną postępowaniach, które przesyłane są przez właściwe w sprawach organy. ${ }^{20}$

Problematyka działania ePUAP również została dość szczegółowo unormowana w przepisach wykonawczych. Przede wszystkim należy zwrócić uwagę na rozporządzenie w sprawie zakresu i warunków korzystania z elektronicznej platformy usług administracji publicznej. ${ }^{21}$ Opisano tam ,proces” zakładania konta użytkownika, sposób prowadzenia usług administracyjnych oraz warunki wymiany informacji między Platformą a innymi systemami teleinformatycznymi.

Szczególnie ważną ,instytucją" wdrożoną w ramach funkcjonalności ePUAP jest tzw. ,profil zaufany”. Profil zastępuje niejako podpis elektroniczny, co w połączeniu z możliwością bezpłatnego jego uzyskania (podpis elektroniczny z kwalifikowanym certyfikatem jest płatny) stanowi korzystne rozwiązanie z punktu widzenia wdrażania e-administracji. Zasady tworzenia, potwierdzania, zmiany i unieważniania tegoż profilu również zostały zawarte w akcie wykonawczym do uinf. Uczyniono to $\mathrm{w}$ ramach rozporządzenia MSWiA w sprawie zasad zatwierdzania, przedłużania ważności, wykorzystania i unieważniania profilu zaufanego elektronicznej platformy usług administracji publicznej. ${ }^{22}$ Określa się tam zarówno podmioty właściwe w sprawach profilu (tzw. punkty zatwierdzające, tj. organy administracji rządowej oraz konsulów), warunki składania podpisu, archiwizowania dokumentów związanych z profilem i wzory wniosków o potwierdzenie, przedłużenie ważności i unieważnienie profilu, jak również okres jego ważności (3 lata), ${ }^{23}$ zawartość (imię, nazwisko, PESEL, identyfikator użytkownika i profilu, czas potwierdzenia ważności, termin ważności, adres poczty elektronicznej użytkownika oraz określenie sposobu autoryzacji $\mathrm{i}^{24}$ ), jak też przesłanki utraty ważności (użycie nieprawdziwych lub nieaktualnych danych, usunięcia konta użytkownika, zmiany danych, na podstawie których konto było rejestrowane, upływ okresu potwierdzenia lub przedłużenia $\left.{ }^{25}\right){ }^{26}$

Profil zaufany nie jest jedynym sposobem potwierdzania tożsamości obywateli, osób prawnych i jednostek organizacyjnych, chcących skorzystać z usługi administracji publicznej. Drugim sposobem jest podpis elektroniczny potwierdzany kwalifikowanym certyfikatem. Również i w tym przedmiocie mamy do czynienia ze spójną i konkretną regulacją normatywną. Przepis art. 20a uinf określa ogólne prawo

Zob. art. 19 b ust. 2 i 3 uinf.

Rozporządzenie MSWiA z dn. 27 kwietnia 2011 r. w sprawie zakresu i warunków korzystania z elektronicznej platformy usług administracji publicznej, Dz.U. Nr 93, poz. 546 (dalej jako Rozporządzenie ePUAP).

Rozporządzenie MSWiA z dn. 27 kwietnia 2011 r. w sprawie zasad zatwierdzania, przedłużania ważności, wykorzystania i unieważniania profilu zaufanego elektronicznej platformy usług administracji publicznej, Dz.U. Nr 93, poz. 547 (zwane dalej Rozporządzeniem w sprawie profilu).

Zob. §8 ust. 1 Rozporzadzenia w sprawie profilu.

Zob. §6 Rozporządzenia w sprawie profilu.

Zob. §11 Rozporządzenia w sprawie profilu.

Zob. §1 Rozporządzenia w sprawie profilu. 
do potwierdzania tożsamości (w ramach postępowań elektronicznych) również tym „sposobem”. Natomiast ustawa o podpisie elektronicznym ${ }^{27}$ tworząc definicję wskazuje, że jest to elektroniczne zaświadczenie, za pomocą którego dane służące do weryfikacji podpisu elektronicznego są przyporządkowane osobie składającej podpis elektroniczny, a jednocześnie umożliwiają identyfikację. „Kwalifikacja” tego zaświadczenia następuje poprzez wydanie certyfikatu (dla tego zaświadczenia) przez podmiot świadczący usługi certyfikacyjne.

Nie tylko zagadnienia organizacyjne, ustrojowe i techniczne zostały uregulowane w obowiązującym prawie. Korzystanie z narzędzi teleinformatycznych wymaga również odpowiednio „dostosowanej” procedury administracyjnej. Wydaje się, że również przepisy postępowania administracyjnego pozwalają na skuteczne załatwianie spraw w drodze elektronicznej. Prawodawca - w k.p.a. - określił sposób prowadzenia postępowania administracyjnego w ogólnym zakresie, posiłkując się unormowaniami obowiązujących ustaw szczególnych. Już od „etapu” wszczęcia procedury widoczne są dość spójne i jednolite regulacje.

Wszczęcie postępowania administracyjnego $\mathrm{w}$ formie elektronicznej na wniosek, tj. za pomocą podania, zostało przewidziane art. 63 k.p.a. Wskazano tam, że podania mogą być wnoszone również za pomocą środków komunikacji elektronicznej przez elektroniczną skrzynkę podawczą organu administracji publicznej i powinny spełniać inne wymagania ustawowe. Jednocześnie zaliczono do nich: uwierzytelnienie przy użyciu mechanizmów określonych w ustawie o informatyzacji działalności podmiotów realizujących zadania publiczne ${ }^{28}$ oraz realizację wymogów dotyczących formatów danych elektronicznych.

Doręczenie dokumentów elektronicznych uzależnione zostało od rodzaju adresatów czynności organu. Doręczenie pisma elektronicznego osobie fizycznej polega na wysłaniu na adres mailowy adresata informacji, iż może on odebrać dokument $\mathrm{w}$ formie elektronicznej wraz ze wskazaniem adresu, z którego owe pismo można pobrać i pod którym powinien dokonać potwierdzenia doręczenia oraz pouczeniem dotyczącym sposobu odbioru. ${ }^{29}$ Natomiast w przypadku osoby prawnej doręczenie następuje bezpośrednio poprzez elektroniczną skrzynkę podawczą adresata. ${ }^{30}$

Wdrożenie e-procedur w postępowaniach administracyjnych obejmuje również zmianę zasad udostępniania dokumentów i akt sprawy podmiotom do tego uprawnionym. Przepis art. $73 \S 4$ k.p.a. ogranicza wgląd do akt sprawy za pośrednictwem sieci teleinformatycznych jedynie do dokumentów elektronicznych wnoszonych do organu bądź przez niego doręczanych. ${ }^{31}$

\footnotetext{
27 Ustawa z dn. 18 września 2001 r. o podpisie elektronicznym, Dz.U. z 2001 r. Nr 130, poz. 1450 z późn. zm.

28 Ustawa $z$ dn. 17 lutego 2005 r. o informatyzacji działalności podmiotów realizujących zadania publiczne, Dz.U. $2005 \mathrm{Nr}$ 64, poz. 565 z późn. zm. (zwana dalej ustawą o informatyzacji).

Zob. art. 46 § 4 k.p.a.

Zob. art. $46 \S 6$ k.p.a.

Szerzej D. Kościuk, Elektroniczne postępowanie administracyjne w sprawach indywidualnych, w świetle zmian Kodeksu Postępowania Administracyjnego, [w:] Funkcjonowanie samorządu gminnego w Polsce, P. Pietrasz,
} 
Postępowanie administracyjne kończy się zazwyczaj wydaniem decyzji lub wyjątkowo - postanowienia. Oba rozstrzygnięcia mogą być wydane w formie dokumentu elektronicznego i dotyczą ich jednolite rozwiązania w zakresie wymagań formalnych niezbędnych do oceny poprawności ich wydania. Przypis art. $107 \S 1$ k.p.a. dotyczący decyzji, jak i przepis art. $124 \S 1$ k.p.a. odnoszący się do postanowień stanowią, iż rozstrzygnięcia powinny być opatrzone bezpiecznym podpisem elektronicznym weryfikowanym za pomocą ważnego kwalifikowanego certyfikatu bądź podpisem osobistym.

Regulacje dotyczące e-postępowania nie pomijają również problematyki odwołania od decyzji. W art. $138 \S 4$ k.p.a. wskazano, że jeśli przepisy odrębne przewidują wydanie decyzji na blankiecie urzędowym, w tym za pomocą środków komunikacji elektronicznej oraz istnieją podstawy do zmiany zaskarżonego aktu, organ odwoławczy uchyla decyzję zobowiązując niższą instancję do wydania decyzji o określonej treści. W praktyce polega to na wskazaniu - przez organ uchylający niezgodną z prawem decyzję - na poprawny formularz elektroniczny zawierający treść decyzji bądź nakaz zmiany treści formularza w celu jego doprowadzenia do zgodności z obowiązującym prawem. ${ }^{32}$

W uzupełnieniu rozważań nad zbiorem przepisów umożliwiających prowadzenie spraw administracyjnych on-line, nie sposób nie wspomnieć o obowiązującym rozporządzeniu w sprawie instrukcji kancelaryjnej, jednolitych rzeczowych wykazów akt oraz instrukcji w sprawie organizacji i zakresie działania archiwów zakładowych. ${ }^{33}$ Przepis $\S 1$ ust. 3 tegoż aktu wyraźnie umożliwia kierownikowi jednostki organizacyjnej (organowi) wybór pomiędzy postępowaniem z dokumentacją w systemie tradycyjnym (papierowym) bądź w ramach EZD (Elektronicznego Zarządzania Dokumentacją). System EZD umożliwia dokonywanie czynności kancelaryjnych, dokumentowanie przebiegu załatwiania spraw oraz gromadzenie i tworzenie dokumentów elektronicznych. Regulacje powyższego rozporządzenia są tak szczegółowe, że pozwalają zarówno na gromadzenie przyporządkowanych do konkretnych spraw wszelkich dokumentów elektronicznych, prowadzenie rejestru przesyłek „wpływających” i wychodzących, wykonywanie dekretacji, dokonywanie akceptacji (tj. podpisywanie dokumentów podpisem elektronicznym) oraz prowadzenie niezbędnych rejestrów i ewidencji. ${ }^{34}$

Podsumowując zatem, można bez wątpliwości potwierdzić istnienie dość jednolitych (od strony ustrojowej, jak i proceduralnej) regulacji prawnych, umożliwiających unikanie nadmiernego (a nawet jakiegokolwiek) zużycia papieru w działaniach biurokracji administracyjnej. Wyraźnie „widoczne” i stosunkowo zrozumiałe jawią

K. Gawrońska, D. Kościuk, J. Kulikowska-Kulesza, M. Perkowska (red.), Białystok 2012, s. 71-73.

Rozporzązenie Prezesa Rady Ministrów z dn. 18 stycznia 2011 r. w sprawie instrukcji kancelaryjnej, jednolitych rzeczowych wykazów akt oraz instrukcji w sprawie organizacji i zakresie działania archiwów zakładowych, Dz.U. Nr 14, poz. 67 (dalej jako instrukcja kancelaryjna). 
się unormowania dotyczące informatyzacji administracji z punktu widzenia ,technologicznego" oraz szczegółowych założeń wymiany informacji w drodze elektronicznej (w tym dokumentów elektronicznych), jak również prowadzenia postępowań administracyjnych z pominięciem drogi tradycyjnej (papierowej). Istnienie regulacji prawnych nie oznacza automatycznie, że zostaną one wdrożone w praktyce, albowiem ogromne znaczenie ma tzw. „czynnik ludzki”, tj. chęć przyswojenia nowej wiedzy i umiejętności. Bez wątpienia jednak podstawy prawne rozpoczęcia „rewolucyjnych" działań na szeroką skalę, polegających na zupełnej rezygnacji z papieru w działaniach administracji, już istnieją i stanowią dość spójny i zrozumiały system normatywny.

\section{BIBLIOGRAFIA}

Bukowski Z., Konstytucyjne podstawy obowiązków państwa w zakresie ochrony środowiska, „Prawo i Środowisko" 2002, nr 4.

Gerwin M., Plan zrównoważonego dostępu dla Polski. Lokalne inicjatywy rozwojowe, Sopot 2008.

Kościuk D., Elektroniczne postępowanie administracyjne w sprawach indywidualnych, w świetle zmian Kodeksu Postępowania Administracyjnego, [w:] Funkcjonowanie samorządu gminnego w Polsce, P. Pietrasz, K. Gawrońska, D. Kościuk, J. Kulikowska-Kulesza, M. Perkowska (red.), Białystok 2012.

Krzywoń A., Konstytucja RP a środowisko, „Państwo i Prawo” 2012, nr 8.

Maciejewska J., Bezpieczeństwo ekologiczne, jako konstytucyjny obowiązek państwa, PPOŚ 2009, $\mathrm{nr} 2$.

Roliński M., Ewolucja pojęcia prawnego „środowiska” i „ochrona środowiska”, „Studia Iuridica Lublinensia" 2005, nr 6 .

Stoczkiewicz M., Zasada zrównoważonego rozwoju, jako zasada prawna, „Prawo i Środowisko” 2001, nr 1.

Żwawa A., Piły i piłki - nie kibicuj niszczeniu lasów!, http://zielonewiadomosci.pl/tematy/ekologia/ pilki-i-pily-nie-kibicuj-niszczeniu-lasow/

Żwawa A., Noszczyk M., Huma M., Przemysł drzewno-papierniczy, http://www.ekonsument.pl/ a66525_przemysl_drzewno_papierniczy.html 


\section{SUSTAINABLE DEVELOPMENT AND ADMINISTRATIVE BUREAUCRACY PAPER}

Around half of the world's annual timber production is processed into paper. For its part in the use of this commodity, it seems that the public administration in Poland does not implement the principle of sustainable development. However, there are legal instruments available to change this situation. These are the regulations concerning the computerization of government and the specifics of the exchange of information by electronic means (including electronic documents), as well as conducting paperless administrative proceedings. At the same time the existence of such regulations does not mean that they are implemented in practice.

Keywords: e-government, administrative procedure, sustainable development 